\title{
The Main Trends in the Development of Internal Audit and the Transformation of the Term "Internal Audit" Essence in Russia
}

\author{
Taran O.L. \\ Department of Economics, Management and Finance \\ Pyatigorsk State University \\ Pyatigorsk, Russia \\ oleg-taran@yandex.ru
}

\author{
Lazareva N. A. \\ Department of International Finance and Accounting \\ St. Petersburg University of Management Technologies and \\ Economics \\ St. Petersburg, Russia \\ natalylazarev.1972@mail.ru
}

Uzdenova S. B.

Department of Tourism and Hospitality, Institute of Service, Tourism and Design

North-Caucasus Federal University

Pyatigorsk, Russia

Uzsony1@yandex.ru

\begin{abstract}
Based on a systematic study of the formation and development of internal audit in Russia, the article shows the importance of internal audit in the economic activities of economic entities, defines the stages of formation and development of the internal audit system in Russia. It is shown that the processes of formation and development of internal audit have led to the fact that in modern economic reality, the priority task of internal audit is to identify and implement the internal reserves of the financial and economic activities of the organization, through the development of recommendations of the auditor, as well as monitoring by the internal auditor of the implementation developed recommendations. Based on a study of the approaches to determining the content of the concept of "internal audit" existing in the economic literature, as well as an analysis of the terms contained in various regulatory legal acts and other sources, an author's definition of internal audit is proposed, aimed at setting and achieving strategic business goals with the development of specific recommendations on leveling the risks of their achievement and possible managerial decisions ensuring the effective conduct of financial and economic activities identity of a particular organization.
\end{abstract} audit.

Keywords—internal audit; stages of development of internal

\section{INTRODUCTION}

Owners of various organizations and managers directly managing these organizations want to not only know the current financial and economic status of the organization, but also its capabilities, as well as ways to achieve these opportunities, and therefore the relevance of the internal audit system is growing, which causes a certain the need to study the essence of internal audit and improve its quality.

\section{LITERATURE REVIEW}

In the history of economic science, the emergence of internal audit is primarily associated with the processes of the growth of business entities and the emergence of difficulties in managing these business entities, when the owners of organizations began to understand that in order to maximize the profit of an economic entity, it is necessary not only to ensure the reliability of accounting and the correctness of all financial and economic operations, but also provide effective management of all financial and economic processes to improve activities of an economic entity as a whole. Such an important awareness of the need for the implementation and development of internal audit generated a lot of controversy regarding its organization and functioning.

Gradually, the role of internal audit in ensuring the efficiency of business entities led to the separation of internal audit as an independent type of audit, as well as an independent profession, the impetus for this was, first of all, that the key task of external auditors was to verify the reliability of financial statements, at that time how internal audit is interested in evaluating all activities of an economic entity.

The scientific interpretation of the term "internal audit" originates from the emergence of the concept "Institute of Internal Auditors", published in the book of V. Brink "Internal Audit" [1] in 1941. The founders of the Institute of Internal Auditors (IIA) argued that the activities of the internal auditor boil down to a comprehensive and independent review of the entire business of an entity, and therefore went beyond verifying the accuracy of financial statements - the main goal of the external auditor. In addition, the Institute of Internal Auditors, argued that the activities of the internal auditor, are 
The stages of development of internal audit highlighted by not limited to accounting, and in January 1942 released the second book, Internal Audit: A New Management Technology.

At the same time, despite the isolation of internal audit as an independent type of audit activity in practice, the term "internal audit" itself is interpreted differently in the economic literature.

\section{RESEARCH METHODOLOGY}

The research methodology is based on the use of theoretical and empirical research methods of theoretical and practical material on the research topic.

\section{RESULTS}

The development of internal audit as an independent type of audit activity is largely connected with the activities of the Institute of Internal Auditors, in support of the foregoing we will give only a few examples of the Institute of Internal Auditors in the scientific and practical promotion of the idea of highlighting internal audit, so after the release of two books in 1941-1942, with 1944 The Institute of Internal Auditors began to publish the journal "Internal Auditor", since 1947. The Institute of Internal Auditors began to study the issue of responsibility of the internal auditor, etc., as a result of all the activities of the Institute of Internal Auditors in the early 1970s, a code of ethics for the internal auditor, a certification program for internal auditors and the first 30 standards of internal audit appeared in 1974 In the USA, the first exam for a certified internal auditor was passed.

Nevertheless, the processes of transformation of internal audit in Russian and world practice continue to this day, going through more and more new stages of its development.

The study of the history of the emergence and development of internal audit, allowed us to highlight certain stages of its development:

At the first stage of the development of internal audit, in our opinion, it was focused on the study of the reliability of the accounting (financial) statements, verification of compliance with applicable laws and the assessment of the internal control system in the organization of the audit object. This stage, in our opinion, existed before the adoption in 1978 of international standards for internal audit.

The second stage of the development of internal audit, in our opinion, was associated with the emergence in the 1990s of the concept of risk management and its introduction into the practice of internal audit to effectively manage the risks of the organization and prevent bankruptcies.

The third stage of the development of internal audit (from the beginning of the 2000s to the present), in our opinion, is associated with the development of strategic planning and the need to increase the competitiveness of the organization by identifying and implementing internal reserves in financial and economic activities, in order to reduce the cost of production or services and achieving the strategic goals of the organization. us are characteristic in general for the global processes of development of internal audit, at the same time, in our opinion, the fourth stage can be distinguished for Russian conditions - this stage began in the summer of 2018, when, thanks to the activities of the Ministry of Economic Development of the Russian Federation and other interested parties, departments and government agencies found that "the main thing is not the name or configuration of the various elements of control necessary for the successful operation of organizations, but adequate A corporate governance framework for the tasks and functions that these organizations perform. Since the summer of 2018, risk management and internal control, as well as internal audit as one of their most important elements have become mandatory for public jointstock companies" [2].

At the same time, it was possible to combine the requirements for organizing an internal audit, which proved its necessity and effectiveness, with traditional approaches in the person of an audit committee: if shareholders want them to have such a commission as some familiar element of direct compliance-control, let it remain, especially if its presence is justified by the history of development or the special functions of the company.

Perhaps this is one of the few examples of a positive solution to a long dispute, when during discussions and negotiations of experts they managed to resolve mutual disagreements, overcome the difficulty of perceiving international standards, largely based on English-language concepts and definitions, previously unknown and even foreign to Russian practice. Moreover, many more processes described in the Standards need to be filled with real content in practice.

Although the starting point for the application of the International Standards of Internal Auditing in Russian organizations can be considered attempts to enter international capital markets at the beginning of the 2000s, many professional managers and economists believe that the construction of large-scale infrastructure projects (sports, transport) played a key role in their practical application and filling with meaning. (industrial, energy, innovative) that have truly global significance even in today's geopolitical environment - as they say, every cloud has its silver lining.

Thus, we can conclude that the processes of formation and development of internal audit have led to the fact that in modern economic reality the priority task of internal audit is to identify and implement the internal reserves of the financial and economic activities of the organization, by developing recommendations of the auditor, as well as monitoring them implementation.

The term "internal audit" in Russia for the first time received a regulatory definition in the federal rule (standard) of audit activity No. 29 "Review of the work of internal audit", approved by the Government of the Russian Federation on August 25, 2006 No. 523, in which internal audit refers to control activity carried out within the audited entity by its unit - the internal audit service. 
Internal audit from the position of internal control is also

Filevskaya N.A. in his research notes, "International Professional Standards of Internal Auditing (IPSIA) define internal audit in terms of a functional approach in three areas: in terms of control, in terms of risk management and in terms of corporate governance. Based on the MPSAA standards, the following definition has been formulated: internal audit is a set of control and analytical procedures for independent, objective assessment and verification of the audit object in order to provide reliable and timely information to the subjects of corporate relations, which helps to increase the efficiency of risk management, internal control and corporate governance processes" [3].

Filevskaya N.A. clarifying the term "internal audit" considers it, primarily from the perspective of a set of control and analytical procedures.

Alborov R.A. [4] considers the internal audit in the form of an independent audit by the internal auditor of the organization's activities in its interests.

Suyts V.P., Akhmetbekov A.N., Dubrovina T.A. [5] also consider internal audit as the interest of the organization itself in the results of the audit of financial and economic activities, in essence, identifying the internal audit with audit activities.

Skobara V.V. in his writings notes that "Internal audit is carried out by a person who is in the state of an economic entity, and is a necessary element of managerial control in organizations of all forms of ownership. The main purpose of the internal audit is information support of the organization's management bodies" [6].

These authors associate the concept of "internal audit" with the internal audit activities of the organization, carried out either by internal auditors or audit commissions of the organization itself.

Bychkova S.M., Itygilova E.Yu., Sokolov Ya.V. adheres to a slightly different approach to the definition of internal audit. [7], which consider internal audit from the perspective of an element of internal control by the organization's management over the correctness of the preparation of accounting (financial) statements, as well as control over other areas of the business entity's activities.

From the position of internal control, internal audit is considered in their study by such scientists as Suvorova SP, Khanenko M.E., Pankratova L.A., they note that "In modern economic conditions, internal audit is a form of independent financial and economic control, which provides a comprehensive assessment of the performance of an economic entity and involves the formation of an opinion on the results of activities both in the organization as a whole, and in structural units, centers news, activities and business processes "'[8].

In their study, internal audit from a position of control is considered by S. Makarenko, O. Grabovets, noting - "Internal audit is an activity regulated by internal documents of the organization to control various aspects of the functioning of an economic entity, which is implemented by representatives of an independent control body" [9]. considered in some regulatory legal acts, in particular in the Regulation on the organization of internal audit in the Central Bank of the Russian Federation, internal audit is defined as "... control carried out by conducting regular documentary audits of financial and business aspects of activity" [10].

Rogulenko T.M. notes: "Internal audit is a system of monitoring compliance with the organization and the procedure for conducting primary and accounting and reporting in accordance with applicable law and organizational and administrative documents developed at the enterprise in order to comply with the interests of the owner" [11].

A radically different approach is presented in the textbook edited by professor M.V. Melnik, in which the internal audit is considered from the position of management of organizations in the interests of its leadership, as noted in the framework of the specified training manual, "The definition of internal audit seems correct, according to which it is carried out exclusively in the interests of the organization's leadership, which distinguishes internal audit from other forms of nongovernmental control over the activities of an economic entity, such as external audit and audit" [12].

Also, from a position of management, internal audit is considered by Vasilyeva E.A. and Guskova T.N., who in their scientific article note that "Internal audit is an important management function that covers accounting, financial analysis and control, comparing and evaluating the actually achieved result with the goals and objectives of the enterprise" [13].

Internal audit as part of the organization's management system is considered in their study by A.Yu. Bunin and Yu.V., Zarochintseva who in their study note that "...the internal audit of the organization is the most accurate and independent source of information, helping management in making managerial decisions, as well as in the subsequent assessment of the quality of their implementation" [14].

Differs from the above, the position of such authors as Pugacheva V.V. [15], Bogomolova A.M., Goloshchapova N.A. $[16,17,18,19]$ which, in their studies, consider internal audit as part of a general audit, commissioned by the management of an entity by its structural units.

\section{DISCUSSION}

In our opinion, an internal audit should be presented in the form of a specific add-on regulated by internal documents of the organization over the financial and economic system of the organization, represented by accounting, planning and economic services, marketing services or other similar structures of the organization, depending on the size, legal form of ownership and areas of the organization, and should be aimed at ensuring the effective operation of the organization both in terms of achieving its country strategic goals and objectives, and from the point of view of ensuring efficiency and reliability of all financial and economic activities. 
Based on the foregoing, the following author's definition of internal audit can be proposed - this is an activity to assess the effectiveness of an economic entity in terms of the reliability and effectiveness of conducting financial and economic activities, aimed at developing proposals for its optimization to achieve strategic initiatives and mitigate risks, regulated by internal local regulatory acts.

A distinctive feature of our proposed definition from existing ones is its focus on the formulation and achievement of strategic goals for doing business with the development of specific recommendations for leveling the risks of their achievement and possible management decisions that ensure the efficient conduct of financial and economic activities of a particular organization.

\section{CONCLUSION}

The processes of transformation of internal audit in Russian and world practice continue to this day, going through more and more new stages of their development. The study of the history of the emergence and development of internal audit, allowed us to highlight certain stages of its development:

At the first stage of the development of internal audit, in our opinion, it was focused on the study of the reliability of the accounting (financial) statements, verification of compliance with applicable laws and the assessment of the internal control system in the organization of the audit object. This stage, in our opinion, existed before the adoption in 1978 of international standards for internal audit;

The second stage of the development of internal audit, in our opinion, was associated with the emergence in the 1990s of the concept of risk management and its implementation in the practice of internal audit to effectively manage the risks of the organization and prevent bankruptcies;

The third stage of the development of internal audit (from the beginning of the 2000s to the present), in our opinion, is associated with the development of strategic planning and the need to increase the competitiveness of the organization by identifying and implementing internal reserves in financial and economic activities, in order to reduce the cost of production or services and achieving the strategic goals of the organization.

The stages of development of internal audit highlighted by us are characteristic in general for the global processes of development of internal audit, at the same time, in our opinion, the fourth stage can be distinguished for Russian conditions - this stage began in the summer of 2018, when, thanks to the activities of the Ministry of Economic Development of the Russian Federation and other interested parties, departments and government agencies found that "the main thing is not the name or configuration of the various elements of control necessary for the successful operation of organizations, but adequate A corporate governance framework for the tasks and functions that these organizations perform. Since the summer of 2018, risk management and internal control, as well as internal audit as one of their most important elements have become mandatory for public jointstock companies".

At the same time, it was possible to combine the requirements for organizing an internal audit, which proved its necessity and effectiveness, with traditional approaches in the person of an audit committee: if shareholders want them to have such a commission as some familiar element of direct compliance-control, let it remain, especially if its presence is justified by the history of development or the special functions of the company.

Perhaps this is one of the few examples of a positive solution to a long dispute, when during discussions and negotiations of experts they managed to resolve mutual disagreements, overcome the difficulty of perceiving international standards, largely based on English-language concepts and definitions, previously unknown and even foreign to Russian practice. Moreover, many more processes described in the Standards need to be filled with real content in practice.

Although the starting point for the application of the International Standards of Internal Auditing in Russian organizations can be considered attempts to enter international capital markets at the beginning of the 2000s, many professional managers and economists believe that the construction of large-scale infrastructure projects (sports, transport) played a key role in their practical application and filling with meaning. (industrial, energy, innovative) that have truly global significance even in today's geopolitical environment - as they say Xia, a blessing in disguise.

Thus, we can conclude that the processes of formation and development of internal audit have led to the fact that in modern economic reality the priority task of internal audit is to identify and implement the internal reserves of the financial and economic activities of the organization, through the development of recommendations of the auditor, as well as control by internal auditor for the implementation of the developed recommendations.

The study of approaches to the content of the concept of "internal audit" contained in various sources allowed us to generalize these approaches into several groups.

The first group of researchers considers the internal audit as an integral part of the overall audit, responsible primarily for assessing the reliability of the accounting (financial) statements, while this group of researchers does not endow the internal audit with the functionality to control financial and economic processes and manage business risks.

The second, larger, group of researchers, on the contrary, considers internal audit as a system of control and audit activities of the organization's financial and economic activities [17, 18] with the aim of providing objective information to the organization's management for further management decisions, while the development of measures to improve the activities of the business entity is fixed the management of the organization, and not the internal audit.

The third group of researchers brings the concept of "internal audit" to the definition adopted by the International Institute of Internal Auditors (The IIA), assigning to the internal audit, in 
[3] Filevskaya N.A. Internal audit in the corporate governance system. Candidate's thesis. URL: http://economy-lib.com/vnutrenniy-audit-vsisteme-korporativnogo-upravleniya

addition to the functionality for assessing the reliability of accounting (financial) statements, and conducting advisory activities to optimize the management of financial and economic activities in order to achieve specific strategic business results and risk optimization. Here, in our opinion, it should be noted that the use of a risk-based approach in determining the functional of internal audit is a distinctive feature of the proposed approach to the interpretation of the concept of "internal audit" in contrast to the accepted interpretation of the International Institute of Internal Auditors.

In our opinion, an internal audit should be presented in the form of a specific add-on regulated by internal documents of the organization over the financial and economic system of the organization, represented by accounting, planning and economic services, marketing services or other similar structures of the organization, depending on the size, legal form of ownership and areas of the organization, and should be aimed at ensuring the effective operation of the organization both in terms of achieving its country tagic goals and objectives, and from the point of view of ensuring efficiency and reliability of all financial and economic activities.

Based on the foregoing, the following author's definition of internal audit can be proposed - this is an activity to assess the effectiveness of an economic entity in terms of the reliability and effectiveness of conducting financial and economic activities, aimed at developing proposals for its optimization to achieve strategic initiatives and mitigate risks, regulated by internal local regulatory acts.

A distinctive feature of our proposed definition from existing ones is its focus on the formulation and achievement of strategic goals for doing business with the development of specific recommendations for leveling the risks of their achievement and possible management decisions that ensure the efficient conduct of financial and economic activities of a particular organization.

\section{References}

[1] Brink, V.Z. Internal Auditing: Its Nature and Function and Methods of Procedure. The Ronald Press. 1941, 44.

[2] Malykhin D., Tikhomirov A. International professional standards of internal audit in Russia: in the middle of the road. Vnutrenniy auditor. 2018, 3. URL: https://www.iia-ru.ru/upload/innerauditor/articles/2018_12\%20Vnutrenniy\%20auditor_Malykhin_Tikhomi rov.pdf
[4] Alborov R.A. Audit of organizations in industry, trade and agriculture.M.: Delo i Serves. 2000, pp. 18.

[5] Suyts V.P. Audit: General, banking, insurance. M.: INFRA-M. 2002, pp. 26.

[6] Audit: textbook. M.: Prosveshchenie. 2005, 479.

[7] Audit: monography. M.: Magistr. 2011, 463.

[8] Suvorova S.P. Organizational and technical basis of internal audit. Vestnik OrelGIEHT. 2011, №2(16), pp. 16-22. URL: http://orelgiet.ru/docs/suvorova_hanenko_pankratova_16.pdf

[9] Makarenko S.A. Methodology of internal control and accounts payable accounts receivable. Audit i financial analyze. 2017, 3-4, pp. 169-174. URL: $\quad$ http://www.auditfin.com/fin/2017/34/fin_2017_31_41_rus_04_01.pdf

[10] Regulations on the organization of internal audit in the Central Bank of the Russian Federation: order of the Central Bank of the Russian Federation of March 31, 1997 №02-140 (December, 25, 2002). Legal reference system "Consultant Plus". URL: http://www.consultant.ru/document/cons_doc_LAW_216629/1d8dcf582 4d5241136fa09b9e9c672ac5d325365/. - Data obnovleniya 01.06.2019.

[11] Rogulenko T.M. Internal audit and its place in the system of internal control. Risk: resources, information, supply, competition. 2012, 1, pp. 568-576. URL: https://elibrary.ru/item.asp?id=17805386

[12] Mel'nik M.V. Audit and control. M.: ID FVK-PRESS. 2003, 520. URL: http://www.initkms.ru/umk/bu/download4_2/reviziya_i_kontrol_m.v.me lnik_2003.pdf

[13] Vasil'eva E.A. Internal audit as a fundamental link in the development of internal control in the management system of the organization. Economics and management: new lyrics and perspectives. 2013, 4, pp. 125-127. URL: https://elibrary.ru/item.asp?id=21854065

[14] Bunina A.YU. Internal audit in the organization management system. Voronezh State Agricultural University Bulletin. 2017, 4(55), pp. 217223. URL: http://vestnik.vsau.ru/wp-content/uploads/2018/04/217223.pdf

[15] Pugachev V.V. Internal audit and control. Organization of internal audit in conditions of economic crisis: the textbook. M.: Business and service. 2010, 224.

[16] Bogomolov A.M., Goloshchapov N.A. Internal audit: organization and methodology.M.: Ehkzamen. 2000, 192.

[17] Taran O.L., Adzhienko V.L., Taran I.L. Sanatorium-resort and tourist sphere for the competitiveness of stavropol territory (part 1) The European Proceedings of Social \& Behavioural Sciences EpSBS eISSN: $2357-1330 \quad$ C)2019 Published by the Future Academy.https://dx.doi.org/10.15405/epsbs.2019.04.115

[18] Alexsandr S. Kuznetsov. Russian Professor's meeting. Russian Journal of Physical Education and Sport. 2019, 14(1), pp. 17-22. DOI: 10.14526/2070-4798-2019-14-1-18-24

[19] Taran O.L., Adzhienko V.L., Taran I.L. Sanatorium-resort and tourist sphere for the competitiveness of stavropol territory (part 2) The European Proceedings of Social \& Behavioural Sciences EpSBS eISSN: $2357-1330 \quad$ C 2019 Published by the Future https://dx.doi.org/10.15405/epsbs.2019.04. 